\title{
Benchmarking The Accounting And Finance Functions Of Hong Kong Firms
}

Steven P. Landry (Email: s_landry@ hotmail.com), Monterey Institute of International Studies

Terrance Jalbert (Email: jalbert@ hawaii.edu), University of Hawaii at Hilo Wai Yee Canri Chan (Email: canri.chan@miis.edu), Monterey Institute of International Studies

\begin{abstract}
In this article the results of a Benchmarking study sponsored by the Hong Kong Society for Accountants, Financial Management Committee are reported. The study, in the form of a survey, was sent to 633 listed Hong Kong firms. Sixty-seven firms responded to the survey crossing six different industries and a variety of capitalization levels. The survey consisted of thirty-two questions that addressed seven areas of interest related to the accounting and finance functions within the firms. The results provide benchmarks by which firms can compare their operations to those of other similar firms. Firms can identify strengths, weaknesses and best practices and utilize the information to make changes in their organizations. By doing so, firms may be able to achieve improved competitiveness and increased profitability.
\end{abstract}

\section{Introduction}

I

mproving and enhancing products, services and operations are critical factors for firm survival in the globally competitive market. Benchmarking represents one method a company can use to assess its performance and competitiveness. Benchmarking is the process of evaluating one firm, called a baseline, to a group of peer firms, particularly with respect to best practices. An attribute of one firm is compared to the same attribute of the peer group. This process allows organizations to identify important areas for improvement, analyze outstanding practices within and across the industry, and implement changes to enhance and improve performance. These changes can enhance competitiveness and ultimately improve profitability. The objective of this study was to establish baselines for the finance and accounting functions of listed companies in Hong Kong. These baselines will provide firms reference points for evaluating their operations when performing their own comparative studies. This is the first study to make such data available with respect to Hong Kong firms and thus fills an important void in the literature. Using the data provided here allows firms to initiate their own benchmarking and/or comparative studies. 


\section{The Survey}

To develop the baselines, we surveyed 633 listed companies in Hong Kong under the auspices of the Hong Kong Society of Accountants (HKSA) and the Financial Management Committee of the HKSA. The survey instrument is presented in the Appendix to this article. Surveyed firms were classified into seven groups based on the industry within which the firm operates. The seven classifications are Consolidated Enterprises (CE), Financial (F), Hotels (H), Industrial (I), Property (P), Utility (U) and Miscellaneous (M). Classifications were made based on the collective opinion of the HKSA Financial Management Committee, consisting of approximately 20 members. The committee is composed of academics, corporate controllers, CFOs, and other highranking accounting and finance professionals of major Hong Kong firms. The survey was mailed and responses were received during the first half of 2000. A total of 67 surveys were returned. That constituted an overall response rate of $10.6 \%$ (67 out

Readers with comments or questions are encouraged to contact the authors via email. of a possible 633). Response rates for the various industries ranged from $0 \%$ for the hotel industry to $25 \%$ for the utility industry. Note that given the zero response rate, the hotel industry was omitted from this study.

Capitalization of the responding firms in Hong Kong dollars $(\mathrm{HK} \$)$ is presented in Table 1. For reference, in January of 2000, US\$1 was equivalent to HK\$7.78 (Onada, 2002). The cells in the table indicate the number of firms falling within each capitalization level. Twenty-two firms had capitalization above HK\$1 billion and one below HK\$50 million. The remaining 45 firms had capitalization between HK\$50 million and HK\$1 billion.

The remainder of the paper is organized as follows. In Section 1, the number and quality of the accounting and finance staff are examined. In Section 2, the cost of training the accounting and finance staff are analyzed. In Section 3, the processes of planning budgeting and forecasting are investigated. In Section 4, the preparation and use of interim management accounts are explored. In Section 5, the preparation and use of yearend statutory accounts are analyzed. In Section 6, the extent to which firms use an internal audit department as well as the characteristics of those departments are examined. In Section 7, the extent to which accounting and finance processes are automated are explored. Finally, Section 8 contains concluding remarks.

Table 1: Capitalization of Response Firms

Industry

Market Cap in HK\$'million

50 or less

$50-100$

$100-200$ 


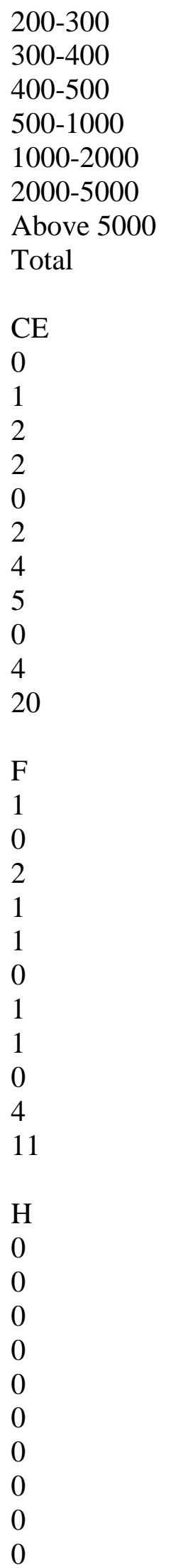




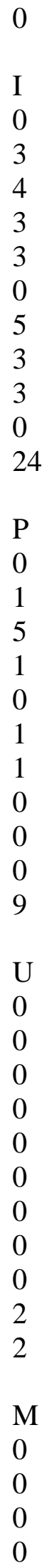


Total

Six questions related to the accounting and finance staff were asked. The first question asked the total number of staff within the firm. The second question asked the number of accounting and finance staff within the firm. Utilizing the data from these two questions, Table 2 presents the ratio of finance staff to total staff. The table contains six columns. The first column indicates the industry being examined. The second column indicates the number of firms that responded to the question. The third column is the average, computed as the sum of finance and accounting staff across the entire sample, within that industry category, divided by the sum of all staff across the entire sample within that industry category. The fourth, fifth and sixth columns indicate the median, maximum and minimum ratio values respectively. The overall average ratio of accounting/finance staff to total staff was $2 \%$ (1:50) while the overall median was $6 \%$ (1:16.6). Translated, this figure indicated that among the firms surveyed, there was one accounting/finance staff for each 50 total staff in the firm. The large difference between the median and the average indicates potential outlier data. Among the six industries, the median was the highest (10\%) in the Consolidated Enterprises industry (1:10) while the median was the lowest $(2.6 \%)$ in the Utility industry (1:38.4). 
We continued by examining the qualifications of the accounting and finance staff. We asked the number of "qualified" accounting and finance staff in the company. Qualified accounting and finance staff were defined as those staff holding a professional designation such as HKSA, CA, ASCPA, CIMA, ACAA, CMA, AICPA, etc. Of interest was the ratio of qualified accounting/ finance staff to total accounting/finance staff. The results are presented in Table 3 . The overall average ratio was $22 \%$ and the overall median was $23.1 \%(1: 4-5)$. The highest average of $39 \%(1: 2.5)$ was for the utility industry while the lowest average was $16 \%$ (1:6.2) in the Property industry. The ratio varied widely among firms.

The next three questions considered the Finance Director. The first question asked if the Finance Director was a member of the Board of Directors. The second question asked if the Finance Director was a qualified accountant. The third question asked if the Finance Director was an HKSA member. We began by examining the percentage of firms whose Finance Director was a member of the Board of Directors. The results are presented in Table 4. Overall, the Finance Director was a member of the Board of Directors in $45 \%$ of responding firms.

We continued by examining the percentage of Finance Directors that were qualified accountants. The results are presented in Table 5. Overall, 70\% of Finance Directors were qualified accountants. $100 \%$ of responding companies in the Financial and Utility industries indicated that the Finance Director was a qualified accountant. In the Property and Consolidated Enterprise industries, only 50\% and $54 \%$ respectively of the Finance Directors were qualified accountants. One might be tempted to interpret this finding as a size effect. However, with the exception of the Utility Industry each of the industry had both large and small firms.

Finally, we examined the extent to which Finance Directors were HKSA (Hong Kong Society of Accountants) members. The results are presented in Table 6. Overall $61 \%$ of Finance Directors were HKSA members. In the Finance and Utility industries, $100 \%$ of Finance Directors were HKSA members. In the Consolidated Enterprise and Industrial categories, 54\% and 69\% respectively of Finance Directors were HKSA members. The firm in the Miscellaneous industry did not respond to this question.

Section 2: The Cost Per Year of Operating and Training the Accounting and Finance Staff

In this section we examined the cost of operating and training the accounting/finance staff. Three questions in the survey addressed this issue. The first question addressed the total staff remuneration for the company. The second question asked the total accounting/finance staff remuneration. For both questions, the respondents were explicitly asked to include the cost of benefits in their calculations. The third question asked about the total external cost of training the accounting/finance staff. The time period for each question was the most recent operating year. We began by first considering total staff remuneration for the firm. The results are presented in Table 7. 
Overall, the average per person per year remuneration was HK\$153,579. The highest median remuneration was in the Utility industry at $\mathrm{HK} \$ 435,747$. The lowest median remuneration of $\mathrm{HK} \$ 7,500$ was in the Miscellaneous industry.

Table 7: Average Per Person per Year (Total Staff) Remuneration

Industry

Responses

Average

Median

Max

Min

CE Total

20

175,009

269,389

$1,166,667$

114,286

F Total

7

265,415

266,139

508,475

206,897

I Total

21

64,777

263,662

642,857

1,600

P Total

9

102,788

145,000

248,397

1,750

U Total

2

453,747

435,578 
489,143

382,012

M Total

1

7,500

7,500

7,500

7,500

Overall

60

153,579

236,667

$1,166,667$

1,600

We continued by examining the total accounting/finance staff remuneration. The results are presented in Table 8 . The overall average remuneration was $\mathrm{HK} \$ 333,876$. The highest average remuneration was in the Utility industry at $\mathrm{HK} \$ 748,603$, more than double the average earned in any other industry. The lowest pay was in the Miscellaneous industry at $\mathrm{HK} \$ 16,667$. The maximum remuneration in any firm was HK $\$ 857,143$ and the lowest was HK\$16,667. The combined evidence from Tables 7 and 8 clearly indicated that accounting/finance staff were better paid, averaging HK $\$ 333,876$, than other staff that average $\mathrm{HK} \$ 153,579$. This finding is consistent with findings elsewhere. The American Assembly of Colleges and Schools of Business (AACSB) reports that finance and accounting faculty average earning US\$98,250 while faculty in other business fields average only US $\$ 83,800$.

We continued by comparing the accounting/finance staff total remuneration to total staff remuneration. The results indicated the percentages of total payroll that were paid to accounting/finance staff and are presented in Table 9. Overall, total accounting and finance staff remuneration was $4.2 \%$ of total firm remuneration. The highest median was $8.3 \%$ in the Miscellaneous industry and the lowest was 3.4\% in the Finance industry.

We turned to the issue of the total annual external annual cost of training accounting and finance staff. The results are presented in Table 10. The overall average cost was HK\$192,387. The highest average was HK\$700,000 in the Utility industry while the lowest average was HK\$60,000 in the Consolidated Enterprise industry. The highest external cost by an individual firm was HK\$1,000,000 and the lowest was HK\$10,000. 
We continued the examination of external training costs by computing the external cost per accounting and finance emp-loyee. The results are presented in Table 11. The overall average exter-nal training cost per accounting and finance employee was HK\$7,053. The highest average external cost per accounting and finance emp-loyee was $\mathrm{HK} \$ 18,000$ in the Pro-perty industry while the lowest was HK\$1,407 in the Financial industry.

\section{Section 3: Planning, Forecasting, and Budgeting}

In this section, we examined the processes of Planning, Forecasting and Budgeting. Seven questions were asked concerning these areas. At issue was the amount of time required to prepare and complete the annual budget and the financial forecasts as well as the quantity and type of human re-sources required for the work. Three questions were related to the annual budget of the firm. The first question asked the number of weeks required to prepare and complete the annual budget each year. The results are presented in Table 12. The overall average 5.5 weeks. The largest was 12 weeks in the Utility industry and the lowest 4.2 in the Consolidated Enterprise industry.

Next, we examined the total Man-Days used to prepare the annual budget. The results are presented in Table 13. The overall average number of Man-Days was 221.4 while the median was 40. Industry averages varied from 40 to 286.2. In some instances the response was not meaningful (NM).

The third question asked the number of Man-Days of the accounting/finance staff required per year to prepare the annual budget. The results are presented in Table 14. The overall average was 105.1. The averages by industry varied from 20 to 151.5. Interestingly, the combined evidence from Table 13 and 14 indicate that less than onehalf of the total hours required to prepare the annual budget are performed by the accounting and finance staff.

We turned to financial forecasts of year-end profits with four related questions. The first question asked the number of weeks required to prepare a financial forecast for year-end profits. The results are contained in Table 15. The average number of weeks was 2.5 with financial firms requiring one week and utility firms requiring six.

The second question asked the number of times per year that the firm updated its financial forecasts. The results are in Table 16. On average, firms updated their financial forecasts 5 times per year. Firms in the Utility industry averaged 8 updates per year, while firms in the Miscellaneous industry updated only twice per year.

The third question inquired about the number of Man-Days required to update the financial forecasts for year-end profits. The results are presented in Table 17. The overall average was 37.5 Man-Days. The highest average Man-Days was in the Utility industry at 208 and the minimum was in the Miscellaneous industry at 10. 
Finally, the fourth question asked if the firm used a rolling forecast. The results are in Table 18. Thirty percent of responding firms indicated that they used rolling forecasts while 70 percent of responding firms indicated that they did not use rolling forecasts. Firms in the Property industry indicated the largest propensity to use a rolling forecast with 66.7 percent of firms offering an affirmative response.

Section 4: Preparation and use of Interim Management Accounts

In this section, we examined the preparation and use of interim management accounts. Four questions addressed this issue. We began by examining the frequency with which the firm prepared management accounts. The first question asked if the firm prepared management accounts monthly, bi-monthly, quarterly, semi-annually, or at some other frequency. The results are presented in Table 19. The results overwhelmingly indicated the most common frequency for preparing management accounts was monthly. Sixtyone of 67 responding firms indicated they prepared management accounts monthly. Two firms provided multiple responses to this question. Each of the multiple responses were incorporated into the table increasing the total number of observations to 70 .

We continued by examining the amount of effort that was required to prepare the monthly management accounts. The second question asked the number of Man-Days required of the accounting/finance staff to prepare the monthly management accounts each year. The results are provided in Table 20. The results indicated an average of 398 Man-Days per year were required to prepare monthly management accounts. The highest average was 620 Man-Days in the Utility industry. The lowest average was 7 Man-Days in the Miscellaneous industry.

Table 19: How Often Does Company Prepare Management Accounts

\author{
Industry \\ Responses \\ Monthly \\ Bi-Monthly \\ Quarterly \\ Semi-Annual \\ Other
}

CE Total

20

20

0

0

0 


F Total
11
10
0
0
0
1

I Total

24

22

0

2

0

0

*P Total

12

6

0

4

2

0

U Total

2

2

0

0

0

0

M Total
1
1
0
0
0
0

Overall
70
61
0


*(Two P Companies provided multiple responses)

We next turned to an examination of the speed with which the monthly management accounts were provided to managers. The third question asked the number of business days after the close of the relevant period before management accounts were available. The results are presented in Table 21. On average, managers were provided the monthly management accounts 18 days following completion of the relevant period. The fastest firms were in the Utility industry where the accounts were available 9 days after close of the relevant period. The slowest firms were in the Industrial industry where it took an average of 23 days for management to receive the accounts.

Finally, we examined who were the recipients of the monthly management accounts. Respondents were offered five potential candidate recipients as well as an "other" category to select from. Where appropriate, respondents were instructed to indicate multiple recipients. The results are presented in Table 22. The CEO (38 firms), CFO (45 firms), Board of Directors (21 firms) and Divisional/Functional Heads (31 firms) were the most common recipients of monthly management accounts.

Section 5: Preparation and Use of Year-end Statutory Accounts

In this section we examine the preparation and use of year-end statutory accounts. Five survey questions addressed this topic. We began by examining the number of Man-Days required to prepare the year-end statutory accounts. The results are provided in Table 23. On average, firms required 196 Man-Days to prepare year-end statutory accounts. The highest average number of Man-Days was in the Utility industry where 380 Man-Days were required. The lowest average was in the Miscellaneous industry where only 30 Man-Days were required.

Table 22: Monthly Management Accounts - Who are the Internal Recipients?

Industry

Responses

CEO

$\mathrm{CFO}$

Board of Directors

Divisional/

Functional Heads

Audit Committee

Others 


CE Total
20
11
11
12
9
0
2

F Total
11
9
6
4
7
1
1

I Total
24
14
19
17
10
1
2

P Total
9
1
6
7
3
3
0

U Total
2
2
2
1
2
0
0




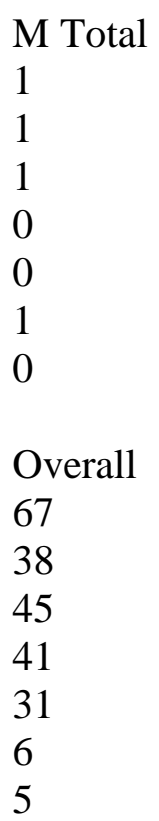

We continued by examining the speed with which the accounts were prepared. We asked the number of business days after the close of the year before statutory accounts were available for audit. The results are presented in Table 24. On average, firms reported that the accounts became available 51 days after year-end. The quickest firms were those in the Utility industry where on average only 21 days were required to produce the yearend accounts. On average, the slowest firms were those classified as Industrial where 64 days were required.

Next, we examined the internal recipients of the year-end statutory accounts. In the third question, respondents are presented five potential candidate recipients as well as an "other" category. The results are presented in Table 25. The results indicated that the CEO (45 firms), CFO (43 firms), Board of Directors (62 firms), Divisional/Functional Heads (23 firms) and the Audit Committee (47 firms) were the most common internal recipients. In only a few cases were the reports provided to other internal recipients ( 5 firms).

Table 25: Year-End Statutory Accounts - Who are the Internal Recipients?

\author{
Industry \\ Responses \\ CEO \\ CFO \\ Directors \\ Heads \\ Audit Committee \\ Others
}




CE Total
20
12
10
18
9
13
1

F Total
11
9
6
10
4
9
3

I Total
24
18
18
23
7
16
1

P Total
9
3
6
8
1
7
0

U Total
2
2
2
2
2
2
0


We then turned to an examination of the annual report. First, we examined the number of Man-Days required to prepare the annual report. The results are presented in Table 26. On average, firms expended 72 Man-Days to produce the annual report. Firms in the Utility industry required an average of 175 Man-Days, the most required by any industry. Firms in the Miscellaneous industry required 20 Man-Days, the least of any industry. Finally, we examined the non-staff cost of preparing the annual report. The intent of this question was to capture printing, translation, public relations, and other costs associated with production of the annual report. The results are provided in Table 27. On average, firms spent $\mathrm{HK} \$ 558,361$ to prepare the annual report, with the highest in the Utility industry at $\mathrm{HK} \$ 1,750,000$ and the lowest in the Miscellaneous industry at HK\$200,000.

Section 6: Internal Audit Depart-ment

In this section, we examined the operations of internal audit departments. Four questions addressed this area. We began by examining the total number of internal audit staff within the firm as asked by question F1. The results are provided in Table 28. The overall average number of internal audit staff was 9 employees. The highest number of internal audit staff was reported to be 28 employees in the Finance industry while the lowest average was 2 employees as reported by both the Industrial and Miscellaneous industries.

We continued by examining reporting relationships for the internal audit department. The second question offered respondents four candidate answers along with an "other" response. The results are presented in Table 29. In decreasing order, firms reported that the internal audit department reported to the Audit Committee (16 firms), Top Executive Management (15 firms), the Board of Directors (11 firms) and others (1 firm). No firms reported that the internal audit department reported to Non-Executive Management. 
Next, we examined the extent to which firms outsourced some element of internal audit activities. The third question addressed this issue. The results are presented in Table 30 . Overall, 7.4 percent of responding firms indicated that they outsourced some element of their internal audit activities. The highest average was in the Property industry where 12.5 percent of firms outsourced some of their internal audit activities.

Table 29: Internal Audit Department Reports to Whom?

\author{
Executive \\ Board of \\ Audit \\ Non-Executive
}

\title{
Industry \\ Responses \\ Mgmt \\ Directors \\ Committee \\ Mgmt \\ Others
}

CE Total
6
3
3
2
0
0

\section{F Total}

6

2

0

4

0

0

\section{Total}

9

5 
P Total

7

3

2

4

0

0

U Total

2

1

0

2

0

0

M Total

1

1

1

1

0

0

Overall

31

15

11

16

0

1

Finally, for those firms responding positively to the previous question, we inquired about the total external cost of outsourced internal audit activities. The results are presented in Table 31. Only 3 firms responded to this question. For those responding firms, average expenditures for internal audit outsourcing cost HK\$466,667.

Table 31: Total External Cost of Outsourcing Internal Audit Activities*

Industry 
Responses

Average

Median

Max

Min

CE Total

0

F Total

0

I Total

2

450,000

450,000

500,000

400,000

P Total

1

500,000

500,000

500,000

500,000

U Total

0

M Total

0 
Overall

3

466,667

500,000

500,000

400,000

Section 7: Automation of Accounting and Finance Processes

In this section, we examined the extent that the accounting and finance processes of the firm were automated. Three questions addressed this issue. We began by asking which accounting systems were automated in the firm. Eleven response options were provided including an "other" category. The results are presented in Table 32. The most common module for automation was the general ledger with 65 automated firms. No firms selected the "other" category.

We continued by examining the number of personal computers (PCs) in the accounting/finance department. Table 33 presents the response summary. Overall, firms reported an average of 21 computers in the accounting/finance department. The largest average number of computers was reported in the Utility industry with 90 computers. The lowest number of computers was reported in the Miscellaneous industry with 8 computers.

Table 32: What Accounting Modules are Automated in Your company?

\section{General}

Act

Act

Fixed

Cash

Asset

Industry

Response 


Ledger
Pay
Rec.
Inv.
Payroll
Assets
Budgeting
Mgt
Costing
Mgt
Consolidation

CE Total
19
19
18
17
10
11
6
2
3
5
4
7

F Total
10
10
4
4
2
6
6
2
3
3
3
2

24
24
18
18
15


P Total

9

9

6

9

1

5

2

1

0

1

5

U Total

2

2

2

2

2

2

2

2

2

2

1

M Total

1

1

1

0

0

1

0

0 
Overall

65

65

49

51

30

39

31

12

13

20

13

19

Table 33: How Many Computers in the Accounting \& Finance Department?

Industry
Responses
Average
Median
Max
Min
CE Total
19
13
8
44
4

F Total
9
35
19
128
2
I Total
22
18


P Total

8

16

13

38

5

U Total

2

90

90

139

40

M Total

1

8

8

8

8

Overall

61

21

10

139

2

Finally, we examined the number of computers as it relates to the number of accounting and finance staff employed. The results are presented in Table 34. The results indicated that on average firms had 0.98 computers per accounting and finance staff person. The highest average ratio of computers was reported in the Property industry with 1.15 computers per staff person. The lowest ratio was reported in the Miscellaneous industry with 0.53 computers per staff person.

Table 34: Ratio of Computers to Accounting \& Finance Staff

Industry

Responses 


Average
Median
Max
Min

CE Total
18
1.01
1.00
1.33
0.50

F Total
9
0.94
1.00
1.27
0.45

I Total
22
0.92
1.00
1.25
0.50

P Total
8
1.15
1.00
3.50
0.33

U Total
2
1.00
1.00
1.00
0.53
0.53
0.53

1.00


Overall

60

0.98

1.00

3.50

0.33

Table 35 reports the total cost of hardware and software for the most recent year for the accounting/finance system. On average, firms reported spending HK\$2,018,308 on hardware and software. The largest average amount was reported by firms in the Utilities industry at $\mathrm{HK} \$ 36,000,000$. The magnitude of these Utility data inflated the average considerably as the median was computed as HK\$400,000. The lowest average amount of $\mathrm{HK} \$ 300,000$ was reported by firms classified as Miscellaneous.

Table 35: Total Cost (Most Recent Year) of Hardware \& Software for the Accounting \& Finance System
Industry
Responses
Average
Median
Max
Min
CE Total
15
697,143
225,000
2,500,000
10,000
F Total
7
668,571
400,000
$2,000,000$
80,000
I Total
20
680,600
350,000
$4,000,000$ 


\author{
P Total \\ 8 \\ 575,000 \\ 700,000 \\ $1,000,000$ \\ 100,000 \\ U Total \\ 2 \\ $36,000,000$ \\ $36,000,000$ \\ $47,000,000$ \\ $25,000,000$ \\ M Total \\ 1 \\ 300,000 \\ 300,000 \\ 300,000 \\ 300,000 \\ Overall \\ 53 \\ $2,018,308$ \\ 400,000 \\ $47,000,000$ \\ 10,000
}

\title{
Section 8: Concluding Comments
}

In this article, we reported the results of a benchmarking study sponsored by the Hong Kong Society for Accountants and its Financial Management Committee. The study consisted of a survey of some 633 listed Hong Kong firms. Sixty-seven firms responded to the survey crossing six different industries and a variety of capitalization levels. The survey consisted of thirty-two questions that addressed seven areas of interest related to the accounting and finance functions within the firms surveyed. From the beginning, it was hoped that the results might provide an initial baseline in order for firms to commence benchmarking their accounting and finance functions. Firms could compare their operations to those of other similar firms; identify strengths, weaknesses and best practices; and utilize the information from this survey to make changes to their firm. By doing so, firms might be able to achieve improved competitiveness and increased profitability. 
While it is hoped that this data will prove useful to Hong Kong firms and the HKSA, some words of caution are warranted. The $10.6 \%$ of responding firms to the total sent out (the "response rate") was lower than what would have been desirable. Low survey responses may be prone to "response bias". Specifically, firms that more likely might respond would be those having relatively more positive responses with regard to the questions asked. The actual respondents may have had characteristics relatively more in common with each other as opposed to what might be found generally in the population of all firms. Consequently, the sample of responding firms may not represent the true underlying population of firms, but rather it may represent only one subset of that population. Also, as noted in the introduction, some of the reported data may represent outlier data. Typically, the outlier problem may show up where the "averages" and "medians" differed significantly. Given the potential problems with response rate bias and outlier data, users should carefully consider how to use the data particularly in an inferential manner.

Notwithstanding some of the potential data issues, this benchmarking study represents a significant first step forward. This was the first set of such data made available with respect to Hong Kong firms thus allowing impetus for firms to initiate their own benchmarking and/or comparative studies. The usefulness of the data from this study will be found first in applying it to respective organizations' internal processes to increase productivity and profitability. In addition, this study can be used as a baseline for future, similar studies, perhaps on an annual basis to provide ongoing, continuous baseline data. This would allow firms to continually adjust and improve. In a dynamic, global business environment, such abilities to adjust and improve can provide competitive advantages to support strategic initiatives.

\section{References}

AACSB website "Salary Data for New Doctorate Hires," Downloaded from www.aacsb.edu on May 27, 2002.

Ondada Corporation (2002), Exchange Rate Quotations, http://www.oanda.com/.

Appendix I: Survey Instrument for Benchmarking the Finance and Accounting Function

I. What industry does your firm operate in?

II. What is the capitalization of your firm?

A. Information concerning your accounting and finance staff.

1. How many staff are there in the company?

2. How many accounting and finance staff are there in the company?

3. How many "qualified" accounting and finance staff are there in the company? (Qualified means a professional designation such as HKSA, CA, ASCPA, CIMA, ACCA, CMA, AICPA, etc.) 
4. Is there a Finance Director on the Board of Directors?

No:

5. Is the Finance Director a qualified accountant?

No:

6. Is the Finance Director an HKSA member?

No:

B. Information regarding the cost of operating and training your accounting/finance function during your most recent operating year.

1. What was the total staff remuneration (including benefits) for your company? $\$$ $\mathrm{M}$

2. What was the total accounting/finance staff remuneration (including benefits)? $\$$ $\mathrm{M}$

3. What was the total external cost of training the accounting/finance staff? $\$$ $\mathrm{M}$

C. Information with regard to Planning, Forecasting, and Budgeting.

1. How many weeks are required per year to prepare and complete the annual budget? weeks

2. How many Man-Days of total company staff are required per year to prepare the annual budget?

Man-

Days

3. How many Man-Days of the accounting/finance staff are required per year to prepare the annual budget?

Man-Days

4. How many weeks, on average, does it take to prepare a financial forecast for year end profits?

weeks

5. How often per year does your company update its financial forecasts for year

end profits?

times per year

6. How many Man-Days of total accounting /finance staff are required per year to update the financial forecasts for year end profits?

Man-Days

7. Does your company use a rolling forecast?

Yes:

No:

D. Information with regard to interim management accounts.

1. How often does your company prepare management accounts?
a. Monthly

c. Quarterly

e. Others (please specify)

d. Half-yearly

b. Bi-monthly

2. How many Man-Days of the accounting/finance staff are required per year to prepare the monthly management accounts? 
Man-Days

3. Management accounts are available within how many business days after the close of the relevant period?

Days

4. Who are the internal recipients of the monthly management accounts? (Please check all that are appropriate)
a. Chief Executive Officer
b. Chief Financial Officer
c. Board of Directors
d. Divisional/Functional Heads
e. Audit Committee

f. Others (please specify)

E. Information regarding preparation of year-end statutory accounts, external audit, and production of the annual report.

How many Man-Days of the accounting/finance staff are required to prepare the year-end statutory accounts? ManDays

Statutory accounts are available for audit within how many business days after the close of the year?

Days

3. Who are the internal recipients of the year-end statutory accounts? (Please check all that are appropriate)
a. Chief Executive Officer
b. Chief Financial Officer
c. Board of Directors
d. Divisional/Functional Heads
e. Audit Committee

f. Others (please specify)

4. How many Man-Days are required to prepare the annual report (excluding your answer to part E2 above)?

\section{Man-Days}

5. What is the total non-staff cost of preparing the annual report in terms of design, translation, public relations, printing, etc?

$\$$ M

F. Information regarding your internal audit department.

1. List the total number of internal audit staff:

2. The Internal Audit Department reports to whom?

Top Executive Management c. Audit Committee Board of Directors d. Non-Executive Management 
e. Others (please specify)

3. Do you outsource any of your internal audit activities?

Yes:

No:

4. If yes, what is the total cost?

G. Information regarding automation of your accounting and finance processes.

1. Which of the following accounting system modules are automated in your company? (Please check all that are appropriate)
a. General Ledger
b. Accounts Payable
c. Accounts Receivable
d. Inventory
e. Payroll
g. Budgeting

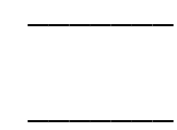
i. Costing
f. Fixed Assets
h. Cash Management
j. Asset Management

k. Others (please specify)

2. How many PCs do you have in your accounting/finance department?

3. What is the total cost of the most recent year of buying/upgrading/maintaining the accounting/finance system (software and hardware)?

$\$$ M

Notes

Journal of Business \& Economics Research

Volume 1, Number 9

PAGE

PAGE

Table 30: Do You Outsource Any Internal Audit Activities?

Industry

Responses

Yes 


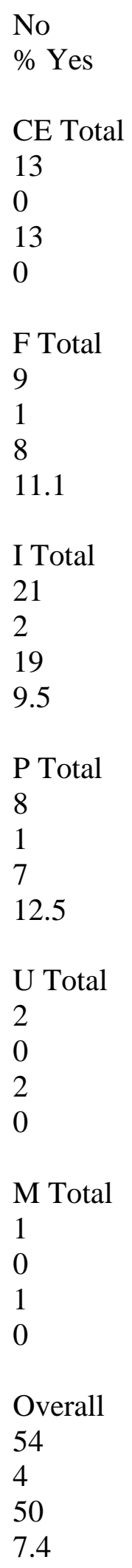


Table 28: Total Number of Internal Audit Staff

(Only includes Companies that Reported Staff)

Industry
Responses
Average
Median
Max
Min
CE Total
6
9
3.5
43
1
F Total
6
28
17.5
71
2
I Total
9
2
1.0
5
1
P Total
7
3
2.0
6
2
U Total
2
13
12.5
18
7




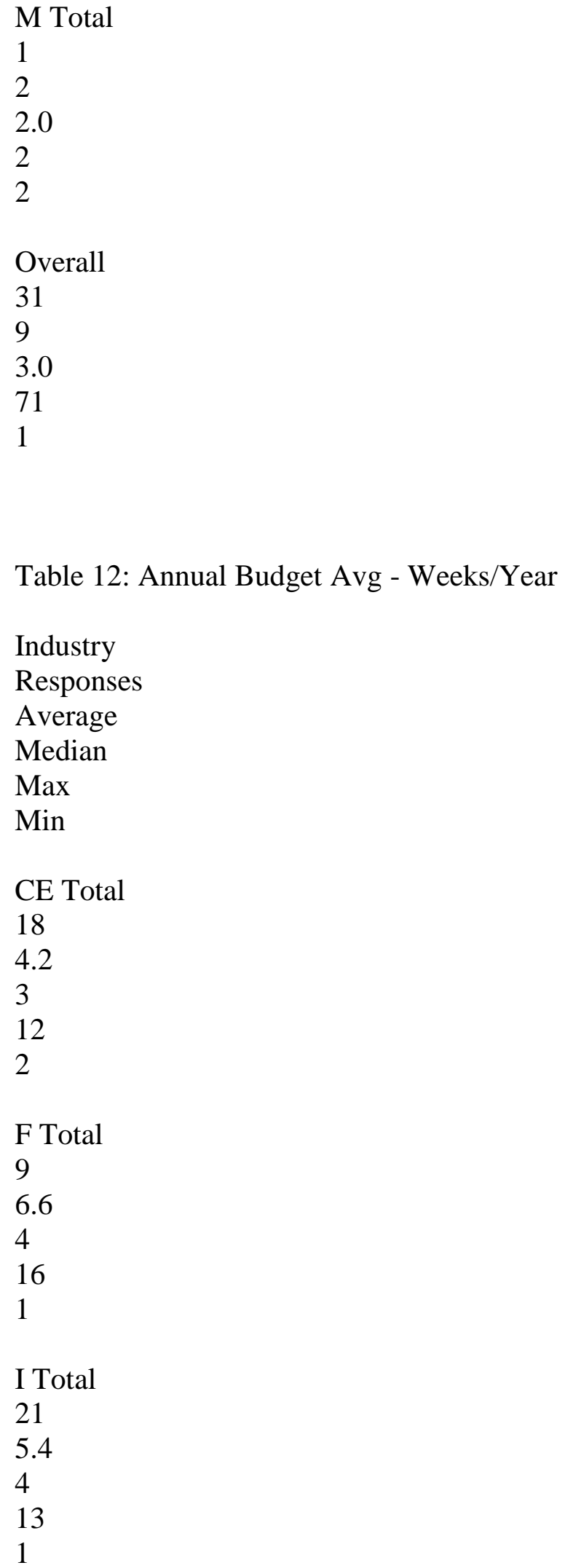

Table 12: Annual Budget Avg - Weeks/Year

Industry

Responses

Average

Median

Max

Min

CE Total

18

4.2

3

12

2

F Total

9

6.6

4

16

1

I Total

21

5.4

4

13

1 


P Total
9
5.8
5
10
1

U Total
2
12.0
12
16
8

M Total
1
5.0
5
5
5
Overall
60
5.5
4
16
1

Table 13: Annual Budget - Average Total Company Staff Man-Days to Prepare

Industry
Responses
Average
Median
Max
Min
CE Total
18
286.2
50
3,000
10




F Total
8
229.5
50
1,109
3

I Total
18
223.0
40
2,000
9

P Total
9
108.9
30
320
10

U Total
2
NM
NM
NM
NM
M Total
1
40.0
40
40
40
Overall
55
221.4
40
3,000
3

Table 14: Annual Budget- Accounting \& Finance Staff Man-Days per Year 


Industry
Responses
Average
Median
Max
Min
CE Total
18
151.5
30
1,500
10

F Total
8
127.4
25
739
1
I Total
18
80.4
20
350
3
P Total
8
53.8
20
150
8
U Total
2
NM
NM
NM
NM
M Total
1
20.0




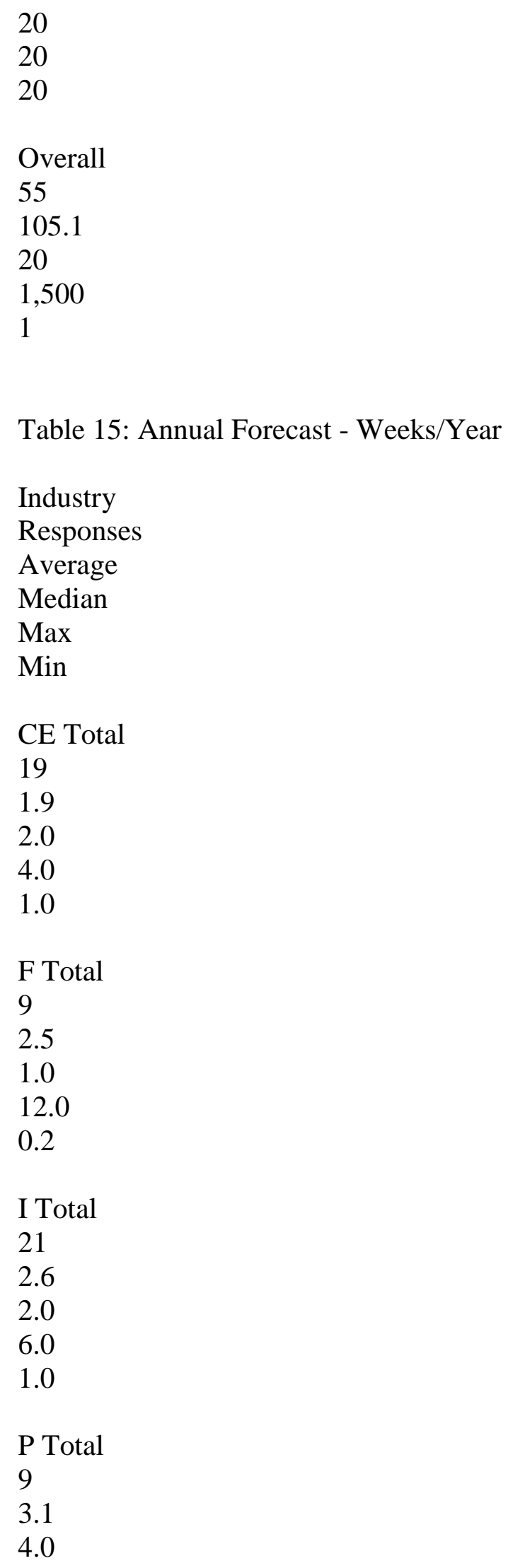


5.0

1.0

U Total

2

6.0

6.0

10.0

2.0

M Total

1

2.0

2.0

2.0

2.0

Overall

61

2.5

2.0

12.0

0.2

Table 26: The Annual Report -

Accounting \& Finance Staff Man-Days per Year

Industry
Responses
Average
Median
Max
Min
CE Total
17
55
30
312
5
F Total
11
150




40
800
14

I Total
22
54
30
300
3

P Total
9
36
30
100
6

U Total
2
175
175
300
50

M Total
1
20
20
20
20

Overall
62
72
30
800
3

Table 27: Total External (Non-Staff) Cost of Preparing Annual Report

Industry

Responses

Average 


Median
Max
Min
CE Total
18
455,556
300,000
$2,000,000$
100,000
F Total
11
552,727
400,000
$2,000,000$
100,000
I Total
20
540,000
345,000
$1,500,000$
100,000
P Total
200,000
9
586,667
500,000
$1,630,000$
100,000
U Total
2
$1,750,000$
$1,750,000$
$2,000,000$
$1,500,000$




\section{Overall \\ 61 \\ 558,361 \\ 400,000 \\ $2,000,000$ \\ 100,000}

Table 23: Year-End Statutory Accounts -

Accounting \& Finance Staff Man-Days per Year

Industry

Responses

Average

Median

Max

Min

CE Total

18

161

100.0

400

10

F Total

9

326

40.0

2,500

20

I Total

21

165

110.0

600

12

P Total

9

184

60.0

1,000

15 


U Total
2
380
380.0
700
60

M Total
1
30
30.0
30
30

Overall
60
196
85.0
2,500
10

Table 24: Year-End Statutory Accounts How Soon Available (Days)?

Industry

Responses

Average

Median

Max

Min

CE Total

20

50

43

94

9

F Total

11

41

30

120 


\section{Total}

24

64

55

150

20

P Total

9

38

45

60

20

U Total

2

21

21

25

16

M Total

1

60

60

60

60

Overall

67

51

45

150

9

Table 20: Monthly Management Accounts - Accounting $\&$ Finance Staff Man-Days per Year

Industry

Responses

Average

Median 


\begin{tabular}{|c|}
\hline $\begin{array}{l}\text { Max } \\
\text { Min }\end{array}$ \\
\hline CE Total \\
\hline 17 \\
\hline 279 \\
\hline 90 \\
\hline 1,680 \\
\hline 5 \\
\hline F Total \\
\hline 9 \\
\hline 307 \\
\hline 48 \\
\hline 1,719 \\
\hline 1 \\
\hline I Total \\
\hline 21 \\
\hline 588 \\
\hline 36 \\
\hline 7,000 \\
\hline 4 \\
\hline P Total \\
\hline 9 \\
\hline 263 \\
\hline 72 \\
\hline 1,000 \\
\hline 6 \\
\hline U Total \\
\hline 2 \\
\hline 620 \\
\hline 620 \\
\hline 1,000 \\
\hline 240 \\
\hline M Total \\
\hline 1 \\
\hline 7 \\
\hline 7 \\
\hline 7 \\
\hline 7 \\
\hline Overall \\
\hline
\end{tabular}


Table 21: Monthly Management Accounts How Soon Available (Days)?

Industry
Responses
Average
Median
Max
Min

CE Total
14
18
15
50
8

F Total
11
20
14
30
5
I Total
24
23
20
60
9
P Total
9
13
15
20
3




U Total
2
9
9
10
7
M Total
1
15
15
15
15

Overall
61
18
15
60
3

Table 8: Average Per Person per Year (Accounting \& Finance Staff) Remuneration

Industry Responses Average Median Max

Min

CE Total

19

315,234

281,746

857,143

22,222

F Total

8

309,854

350,120

500,000

166,667 


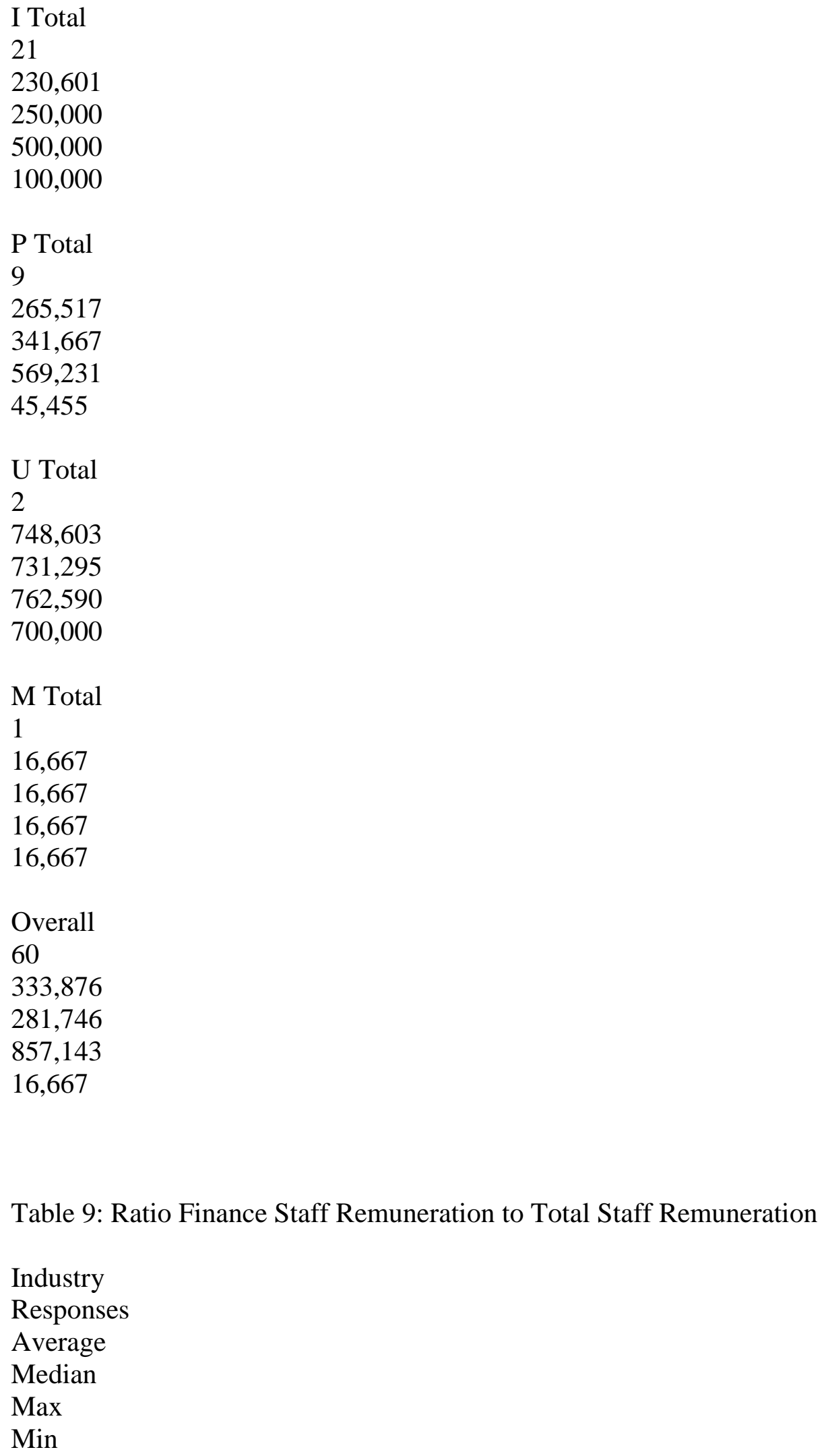

Table 9: Ratio Finance Staff Remuneration to Total Staff Remuneration

Industry

Responses

Average

Median

Max

Min 
CE Total

19

$5.2 \%$

$11.1 \%$

$63.6 \%$

$0.3 \%$

F Total

8

$3.4 \%$

$3.5 \%$

$8.7 \%$

$2.1 \%$

I Total

21

$3.6 \%$

$10.8 \%$

$37.0 \%$

$1.2 \%$

P Total

9

$7.8 \%$

$20.0 \%$

$36.7 \%$

$2.3 \%$

U Total

2

$4.7 \%$

$4.4 \%$

$5.2 \%$

$3.5 \%$

M Total

1

$8.3 \%$

$8.3 \%$

$8.3 \%$

$8.3 \%$

Overall

60

$4.2 \%$ 
$10.8 \%$

$63.6 \%$

$0.3 \%$

Table 10: External Cost of Training Accounting \& Finance Staff Overall Company Cost

Industry
Responses
Average
Median
Max
Min
CE Total
8
60,000
65,000
100,000
10,000

F Total
5
76,000
40,000
200,000
20,000

I Total
9
213,778
54,000
$1,000,000$
10,000

P Total
6
285,000
300,000
500,000
10,000
U Total
2
700,000




700,000
$1,000,000$
400,000

M Total
1
70,000
70,000
70,000
70,000

Overall
31
192,387
100,000
$1,000,000$
10,000

Table 11: External Cost per Accounting \& Finance Person

Industry

Responses

Average

Median

Max

Min

CE Total

7

3,810

3,333

33,333

417

F Total

5

1,407

4,762

20,000

4

I Total

9

6,612 
2,000

25,000

238

P Total

6

18,000

27,564

38,462

833

U Total

2

7,821

13,939

25,000

2,878

M Total

1

4,667

4,667

4,667

4,667

Overall

30

7,053

4,714

38,462

186

Table 16: Annual Forecast - Avg Times/Yr Updated

Industry

Responses

Average

Median

Max

Min

CE Total

18

5.2 


4
12
2
F Total
9
7.2
6
12
1

I Total
21
4.1
3
12
1
P Total
9
4.2
4
12
1
U Total
2
8.0
8
12
4
M Total
1
2.0
2
2
2

Overall
60
5.0
4
12
1


Table 17: Annual Forecast - Accounting

$\&$ Finance Staff Man-Days per Year

Industry
Responses
Average
Median
Max
Min
CE Total
16
23.9
9
144
3

F Total
7
68.0
14
383
1
I Total
18
34.5
20
180
2
P Total
9
49.0
15
160
4
16
16

1
16


M Total

1

10.0

10

10

10

Overall

52

37.5

15

383

1

Table 18: Rolling Forecast (Y or N)

Industry

Responses

Yes

No

$\%$ Yes

CE Total

19

9

10

$47.4 \%$

F Total

9

5

4

$55.5 \%$

I Total

22

9

13

$40.9 \%$

P Total 


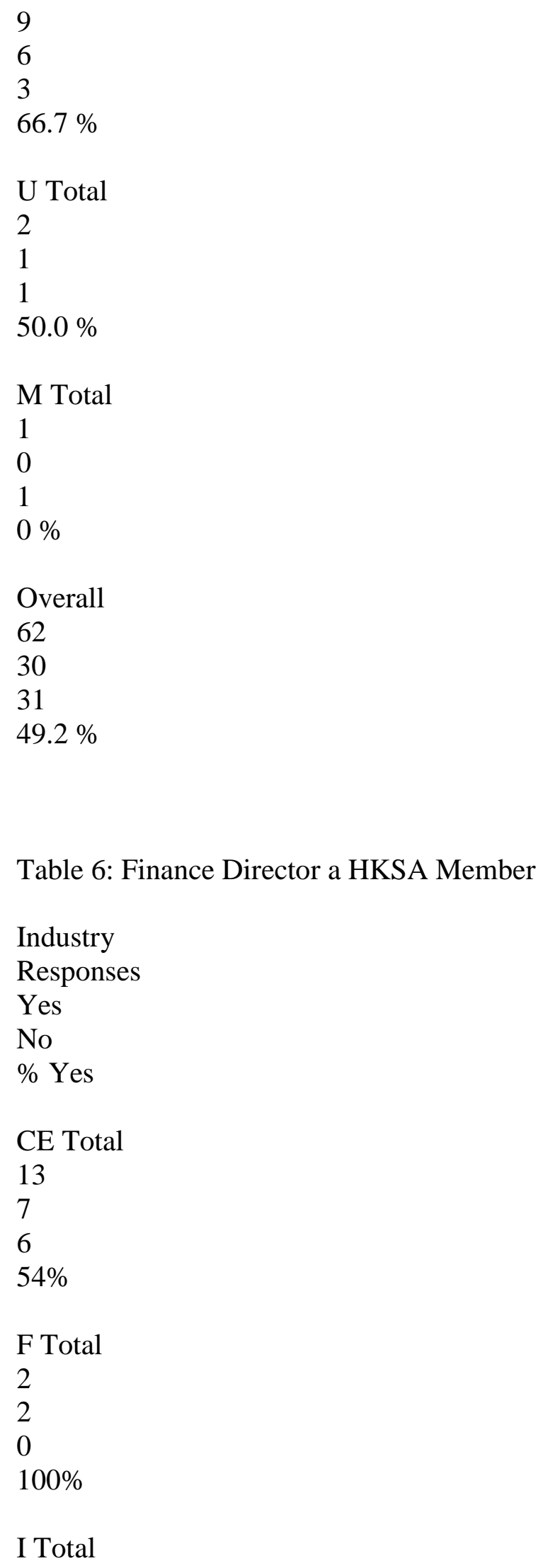

Table 6: Finance Director a HKSA Member

Industry

Responses

Yes

No

$\%$ Yes

CE Total

13

7

6

$54 \%$

F Total

2

2

0

$100 \%$

I Total 


13
9
4
$69 \%$

P Total
2
0
2
$0 \%$
U Total
1
1
0
$100 \%$

M Total
0
0
0

Overall

31

19

12

$61 \%$

Table 5: Finance Director Qualified Accountant

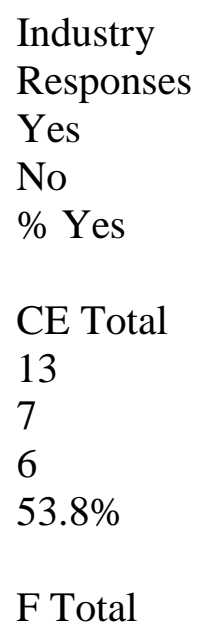




3
3
0
$100 \%$

I Total
14
11
3
$79 \%$

P Total
2
1
1
$50 \%$

U Total
1
1
0
$100 \%$

M Total
0
0
0
.

Overall
33
23
10
$69.7 \%$

$69.7 \%$

Table 4: Finance Director on Board of Directors
Industry
Responses
Yes
No
$\%$ Yes
CE Total 


20
11
9
$55 \%$

F Total
11
2
9
$18 \%$

I Total
24
14
10
$58 \%$

P Total
9
2
7
$22 \%$

U Total
2
1
1
$50 \%$

M Total
1
0
1
$0 \%$
Overall
67
30
37
$45 \%$

Table 3: Ratio of Qualified Finance Staff to Total Finance Staff 


Industry
Responses
Average
Median
Max
Min
CE Total
18
$25 \%$
$31.0 \%$
$57 \%$
$0 \%$

F Total
9
$21 \%$
$22.3 \%$
$100 \%$
$10 \%$

I Total
23
$17 \%$
$17.5 \%$
$50 \%$
$3 \%$

P Total
9
$16 \%$
$23.1 \%$
$50 \%$
$7 \%$
U Total
2
$39 \%$
$36.4 \%$
$40 \%$
$33 \%$
M Total
0




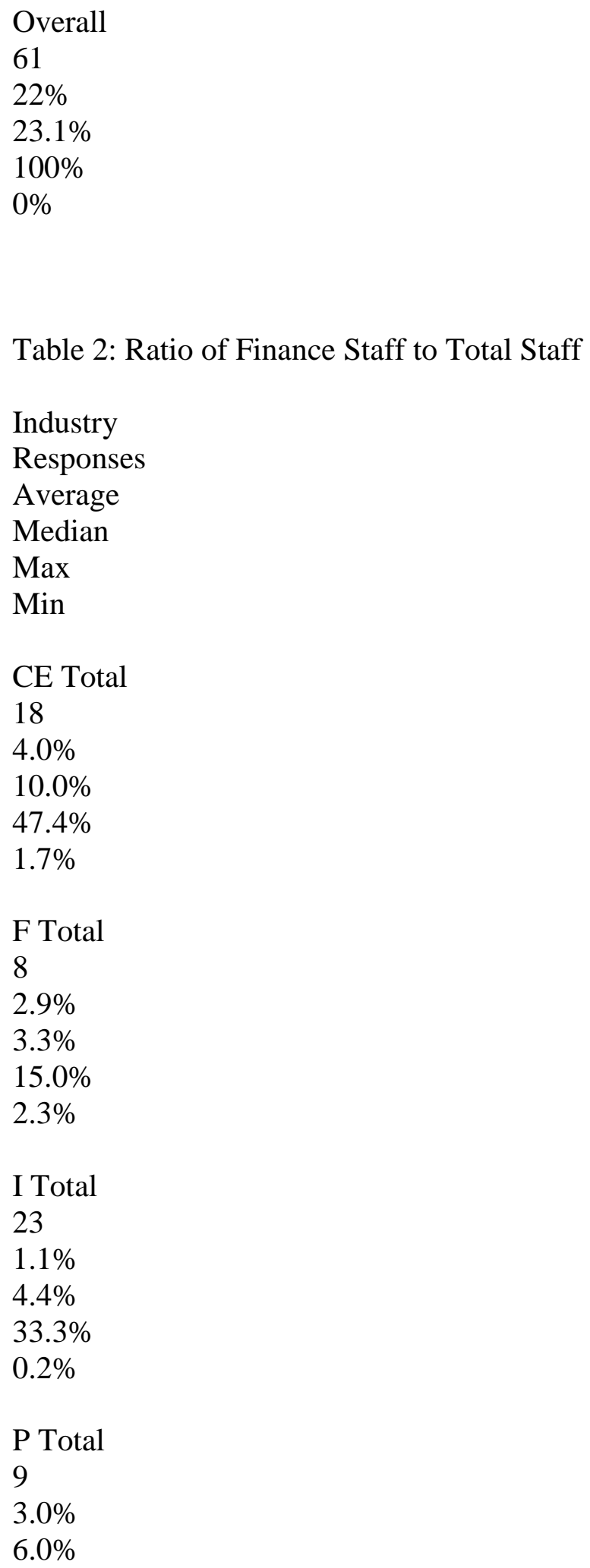

Table 2: Ratio of Finance Staff to Total Staff 


$10.7 \%$
$0.3 \%$
U Total
2
$2.9 \%$
$2.6 \%$
$3.3 \%$
$1.9 \%$

M Total
1
$3.8 \%$
$3.8 \%$
$3.8 \%$
$3.8 \%$

Overall
61
$2.0 \%$
$6.0 \%$
$47.4 \%$
$0.2 \%$

Normal

Normal

Heading 1

Heading 1

Heading 2

Heading 2

Heading 3

Heading 3

Heading 4

Heading 4

Heading 5

Heading 5

Heading 6

Heading 6

Heading 7

Heading 7

Heading 8

Heading 8 
Heading 9

Heading 9

Default Paragraph Font

Default Paragraph Font

Body Text Indent

Body Text Indent

Body Text

Body Text

Body Text Indent 2

Body Text Indent 2

Body Text Indent 3

Body Text Indent 3

Body Text 3

Body Text 3

Hyperlink

Hyperlink

Footer

Footer

Page Number

Page Number

Header

Header

Body Text 2

Body Text 2

$\mathrm{P} 1 / 2 . \mid \mathrm{y} \div \ddot{\mathrm{A}} / @ \mathrm{QC} ? \mathrm{~V}$

$<\mathrm{V} \ddot{\mathrm{y}}$

:

:

:

$:$

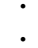

:

:

:

:

:

:

:

:

:

: 
Ronald C. ClutedC:IDocuments and Settings\Owner\Application DatalMicrosoftlWord $\backslash$ AutoRecovery save of Article 526.asd Ronald C. ClutedC:IDocuments and Settings\Owner\Application DatalMicrosoft $\backslash$ Word $\backslash$ AutoRecovery save of Article 526.asd Ronald C. ClutedC:IDocuments and Settings\Owner\Application Data\Microsoft $\backslash$ Word $\backslash$ AutoRecovery save of Article 526.asd 
Ronald C. ClutedC:Documents and Settings $\backslash$ OwnerlApplication DatalMicrosoftlWord \AutoRecovery save of Article 526.asd Ronald C. ClutedC:Documents and Settings\Owner\Application

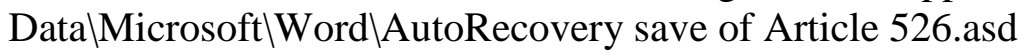
Ronald C. ClutedC:Documents and Settings\OwnerlApplication DatalMicrosoftlWord\AutoRecovery save of Article 526.asd Ronald C. ClutedC:Documents and Settings\OwnerlApplication DatalMicrosoft $\backslash W$ ord $\backslash$ AutoRecovery save of Article 526.asd Ronald C. ClutedC:Documents and Settings \OwnerlApplication DatalMicrosoftlWord \AutoRecovery save of Article 526.asd Ronald C. ClutedC:Documents and Settings\OwnerlApplication DatalMicrosoftlWord\AutoRecovery save of Article 526.asd Ronald C. ClutedC:Documents and Settings\OwnerlApplication

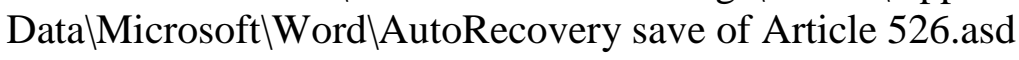
Ronald C. ClutedC:Documents and Settings\OwnerlApplication DatalMicrosoftlWord\AutoRecovery save of Article 526.asd

Ronald C. ClutedC:Documents and Settings\Owner\Application

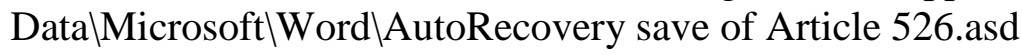
Ronald C. ClutedC:Documents and Settings\OwnerlApplication DatalMicrosoftlWord \AutoRecovery save of Article 526.asd

Ronald C. ClutedC:Documents and Settings $\backslash$ OwnerlApplication DatalMicrosoftlWord \AutoRecovery save of Article 526.asd Ronald C. ClutedC:Documents and Settings\OwnerlApplication DatalMicrosoft $\backslash W$ ord $\backslash$ AutoRecovery save of Article 526.asd

Ronald C. ClutedC:Documents and Settings\OwnerlApplication DatalMicrosoftlWord $\backslash$ AutoRecovery save of Article 526.asd Ronald C. Clute

Ronald C. Clute A:Article 526.doc A: Article 526.doc

Ronald C. Clute

Ronald C. Clute

A: Article 526.doc

A:\Article 526.doc 征7

Unknownÿ !

Times New Roman

Times New Roman

Symbol

Symbol

English111 Vivace BT

English111 Vivace BT

Wingdings

Wingdings

Courier New

Courier New

June 23, 2001 
June 23, 2001

Packard Bell NEC

Packard Bell NEC

Ronald C. Clute

Ronald C. Clute

June 23, 2001

Packard Bell NEC

Normal

Ronald C. Clute

Microsoft Word 9.0

June 23, 2001

Root Entry

1Table

1Table

WordDocument

WordDocument

SummaryInformation

SummaryInformation

DocumentSummaryInformation

DocumentSummaryInformation

CompObj

CompObj

ObjectPool

ObjectPool

Microsoft Word Document

MSWordDoc

Word.Document.8 